\title{
Rational Resistance: Homeowner contention against waste incineration in Guangzhou
}

Amy Zhang

\section{(2) OpenEdition}

1 Journals

Electronic version

URL: http://journals.openedition.org/chinaperspectives/6458

DOI: 10.4000/chinaperspectives. 6458

ISSN: 1996-4617

\section{Publisher}

Centre d'étude français sur la Chine contemporaine

\section{Printed version}

Date of publication: 1 June 2014

Number of pages: $46-52$

ISSN: 2070-3449

\section{Electronic reference}

Amy Zhang, «Rational Resistance: Homeowner contention against waste incineration in

Guangzhou », China Perspectives [Online], 2014/2 | 2014, Online since 01 January 2017, connection on 28 October 2019. URL : http://journals.openedition.org/chinaperspectives/6458; DOI : 10.4000/

chinaperspectives.6458 


\section{Rational Resistance: Homeowner}

\section{contention against waste}

incineration in Guangzhou

AMY ZHANG

ABSTRACT: This article examines the logic and framing of homeowner protests against Waste to Energy (WTE) incineration in Guangzhou. I argue that the concept of "rational resistance" emphasised by homeowner activists represents one way of understanding urban environmental contention in China. Urban homeowners use rational resistance to distinguish themselves from both villagers and the state. Their focus on rationality is a critique of the government's reliance on technology to resolve the social problem of waste management.

KEYWORDS: China, urban environment, homeowners, contentious politics, science and technology studies, waste management, WTE incineration, infrastructure, environmentalism.

"We will express our demands rationally."(1)

1 he first time I heard the term rationality (lixing 理性) was during an interview in the summer of 2010 with urban residents from Panyu, a district in Southern Guangzhou. The conversation took place several months after a protest by local homeowners and villagers had succeeded in suspending a proposal to build a Waste to Energy (WTE) incinerator a few kilometres from their neighbourhood. The interviewees stressed that in their dealings with the government their strategy was to act rationally. Recalling that the literature on local resistance against proposed projects often dismissed as Not-In-My-Backyard (NIMBY) movements - emphasises the tendency for activists to stress that their motives come from reason rather than emotion or self-interest, I paid little attention to the term at the time. (2) However, in subsequent conversations with other homeowners protesting WTE incineration over the next two years, I noticed that the concept of rationality came up repeatedly in interviews, and that it was used both in first-person petitions to government officials and in appeal letters. I began to question how urban environmental protesters used the concept of "rationality" to frame their contentions and express their demands.

This paper examines the current debate over WTE incineration in Guangzhou, China, and how a group of homeowner activists participating in urban environmental contentions understand and frame their own resistance. It examines the reasons they offer as they reject proposed technologies that they and other urban citizens perceive to be of considerable risk to the environment and their health but which are promoted by the state as advanced and safe technology. I focus on homeowners in the Panyu and Huadu districts of Guangzhou who live in gated communities near proposed incineration facilities and who have been the most outspoken members of ongoing anti-incineration actions since 2009. That year, government plans for the construction of WTE incinerators in Guangzhou to deal with the rapidly growing amount of waste spurred a public controversy that received national coverage and attention. Citizens debated where and under what conditions WTE incineration might be an appropriate technology for waste treatment.

Through many hours spent with activists, I discovered that residents held a diverse range of views on WTE incineration. ${ }^{(3)}$ Some consider incinerators harmful or question the state's ability to manage projects, while others say that they support the technology and are interested only in relocating the

This article would not have been possible without the cooperation of many citizen protesters, homeowners, and villagers, who took the risk of opening up to me. Thanks to Anna Lora-Wainwright and Peter Kirby for inviting me to present a version of this paper at the Mapping Environmental Cultures conference at Oxford University in September 2013. Sarah A. Moore gave a sharp commentary on the draft, and I thank Tom Johnson for his thoughtful engagement. Ralph Litzinger provided great comments for extending my argument. Helen F. Siu, as always, offered a patient and thoughtful reading to bring out the central elements of the piece. Thanks also to two anonymous reviewers for their sharp comments and suggestions on additional sources. Special thanks to Bettina Gransow for including me in this issue. This research was conducted with dissertation fieldwork funding from Yale University, the Wenner-Gren Foundation, Social Science Research Council, and National Science Foundation.

1. Interview, 16 August 2010.

2. Kristy Michaud, Juliet Carlisle, and Eric Smith, "Nimbyism vs. environmentalism in attitudes toward energy development," Environmental Politics, Vol. 17, No. 2, 2008, pp. 20-39.

3. This article draws on in-depth interviews with 20 homeowner activists conducted in the summers of 2010 and 2011 and from May 2012 to August 2013. The minimum length of an interview was one hour and the longest four hours. I was able to meet with Huadu homeowners during their ongoing protests and to directly witness their engagement with government officials during monthly trips to petition the municipal city management committee, the department of environmental protection of Guangdong Province and the district city management committee. Interviews with Panyu homeowner activists occurred after the 2009 protest. To juxtapose the perspective of other actors with homeowners, I also interviewed villagers protesting and monitoring incineration facilities and attended public discussion on waste hosted by a local NGO. In addition, I followed online homeowner chat groups and examined letters between homeowners and officials outlining their grievances. I also considered supplementary sources, including policy documents, waste facility planning and environmental assessment reports, and newspaper articles. 
facility further away from their own homes. Moreover, activists from Panyu and Huadu have chosen slightly different focuses. Activists from Panyu highlight the need for recycling, while those from Huadu are primarily interested in provoking the authorities to reconsider the location of a nearby incinerator. However, both groups of homeowners emphasise the "rationality" of their approach.

I argue that homeowners highlight their "rationality" as a discursive device to create a political position for themselves in contrast and opposition to village resisters - their ostensible allies - and to the state, specifically to its approach to modernisation through technological solutions. I argue that framing their resistance as "rational" has two effects for urban homeowner protesters. First, it explicitly separates the form and content of protest by urban homeowners from those of villagers, thereby carving out new modes of contention based on dialogue and negotiation that are in contrast to what homeowners view as villagers' willingness to resort to "emotion." Second, the term "rationality" situates their argument within a scientific discourse aimed at contesting the legitimacy of state policies that rely on technology for waste management. By offering their own more "rational" solution, homeowners argue that the appropriate approach to waste management involves not only a reliance on technology but also an overall shift in the social management of the flow of materials in society. This article starts with a brief background on waste as an urban environmental problem in China and on the resulting nascent homeowner activism in Guangzhou. I situate the rise of homeowner activism within the literature on citizen and environmental contention to examine how rational resistance serves as both a distinguishing tactic and as a critique of the politics of state-led waste management.

\section{Waste as an urban environmental problem in China}

Since economic reform, China's urban waste infrastructure has been increasingly overwhelmed by a growth in consumption and a lifestyle of disposal. In 2004, China surpassed the United States as the world's largest waste-generating nation, and by 2030 China's annual solid waste output is predicted to increase another $150 \%$, from about 190 million tons to more than 480 million tons. ${ }^{(4)}$ Guangzhou's 18 million residents produce 18,000 tons of municipal solid waste each day. ${ }^{(5)}$

WTE incinerators burn waste to produce energy, mostly in the form of electricity or other fuels such as methanol. The Chinese state promotes WTE incineration as the preferred "advanced" technology to deal with the mounting waste crisis. Advocates see the technology as an effective solution for energy recovery with little demand on scarce land. WTE incineration receives state subsidies for renewable energy in China and support from the Asian Development Bank and the Clean Development Mechanism (CDM). State policy documents, such as the "Twelfth Five-Year" Construction Plan for National Urban Household Garbage Harmless Disposal Facilities" (released in 2012), cite goals of treating $35 \%$ of waste through incineration, and over $48 \%$ in more developed east coast cities by the year 2015, up from $12.88 \%$ in 2005 . As of fall 2013, there were two WTE incinerators in Guangzhou, one burning 1,000 tons/day and another burning 2,000 tons/day in its testing stage. By 2015 , the city hopes to increase the total amount of waste treated by WTE incineration to $62 \%$ by building five more facilities. ${ }^{(6)}$

The state's technocratic approach to managing waste through WTE incineration exemplifies a desire for ecological modernisation where waste is metabolised into energy with minimal byproducts. ${ }^{(7)}$ The state's support of WTE incineration is buttressed by what James Scott has called a high modernist ideology, characterised by an unwavering and utopian faith in scientific and technical progress for social improvement. ${ }^{\left({ }^{8}\right)}$ The state relies on waste experts (scientists and engineers) to provide evidence to support official waste management schemes, and by extension, the implicit legitimacy of their vision for the remaking of the modern urban environment. ${ }^{(9)}$

In the process of implementing these plans, however, WTE incineration has brought a group of homeowners who have bought housing adjacent to waste incineration facilities into conflict with the state's modernising projects. Plans to build a large number of WTE incinerators in the last ten years have led to protests in urban centres such as Beijing, Hangzhou, and Wuxi. ${ }^{(10)}$ Disputes over WTE incinerators highlight the tension between the state's desire to use technology as a mark of development and the increasing suspicion of many urbanites towards this ostensibly "advanced" technology. Environmental groups and local residents argue that WTE incineration is both capital-intensive and highly polluting. Weak standards and enforcement often fail to curtail the release of a host of toxins, including fine particulates, heavy metals, and dioxins. Furthermore, protesters argue that incineration weakens the incentive for recycling and other more resourcefriendly methods of waste management. Since the 2009 protests in Panyu, villagers and homeowners in other districts such as Huadu, Baiyun, and Chonghua have engaged in different forms of resistance to existing and proposed facilities.

The waste protesters of Guangzhou represent a growing subset of the urban population who increasingly question and protest urban environmental problems such as suffocating smog, toxic waterways, and high-risk infrastructure. Concerns over the construction of a Maglev (magnet levitation) rail extension in Shanghai in 2008 and anti-Paraxylene (PX) protests in Kunming in early 2013 are some of the more prominent examples of how Chinese citizens are engaging in what the media and observers have called a growing urban environmental consciousness, with participation from not only rural pollution victims and environmentalists but increasingly also from urban residents. ${ }^{(11)}$ While most urban environmental contentions comprise a mix of concerned actors - villagers, students, NGOs, and nearby residents - the organisation and participation of what some scholars have identified as "middle class homeowners" or "upwardly mobile" groups have received

4. World Bank, "Waste Management in China: Issues and Recommendations," May 2005, Working Paper No. 9, Urban Development Working Papers, East Asia Infrastructure Department, World Bank, http://siteresources.worldbank.org/INTEAPREGTOPURBDEV/Resources/China-Waste-Management1.pdf (accessed on 14 March 2014).

5. "Promoting waste recycling: Building a Prosperous Guangzhou," Guangzhou Urban Management Committee pamphlet, 2013

6. "Promoting waste recycling," ibid.

7. Arthur P. J. Mol and David Allan Sonnenfeld (eds), Ecological modernisation around the world: Perspectives and critical debates, London and Portland, OR, Frank Cass, 2000.

8. James C. Scott, Seeing like a State: How certain schemes to improve the human condition have failed, New Haven, CT, and London, Yale University Press, 1998.

9. Sheila Jasanoff (ed), States of Knowledge: The co-production of science and social order, London, Routledge, 2004.

10. Shih-yang Kao, "Beijing Besieged by Garbage: Photographing 'Year One': Wang Jiuliang and the Reign of Garbage," Cross Currents: East Asian History and Culture Review,Vol. 1, 2011, http://crosscurrents.berkeley.edu/e-journal/inaugural-issue (accessed on 29 October 2013).

11. Liu Jianqiang, China's new "middle class" environmental protests," China Dialogue, 1 February 2013, www.chinadialogue.net/article/show/single/en/5561-China-s-new-middle-class-environmental-protests (accessed 2 September 2013); Jeffery Wasserstrom, "The Pollution Crisis and Environmental Activism in China: A Q\&A with Ralph Litzinger," Dissent Magazine, 15 May 2013, www.dissentmagazine.org/online_articles/the-pollution-crisis-and-environmental-activism-inchina-a-qa-with-anthropologist-ralph-litzinger (accessed on 2 September 2013). 
the most attention, particularly since they had previously been characterised as largely apolitical. ${ }^{(12)}$

\section{Homeowner activists}

Scholars are just beginning to turn their focus to an emerging "middle class" or upwardly mobile group of environmental protesters in China who have only recently begun to participate in street protests and to engage with the state. While the men and women I encountered at government petitioning days ${ }^{(13)}$ (jiefangri 接访日), in chat groups, and in interviews were primarily white-collar workers in their mid-30s to mid-50s - for example, computer programmers, business owners, and office assistants - describing urban homeowners as "middle-class" does not address the critical commonality shared by protesters who regard their own identity as distinct. (14) I've stuck to the terminology used by participants to address the two groups that are actively protesting Guangzhou's incinerators: "homeowner" (yezhu 业主), to describe protesters who have moved to newly constructed housing communities, and "villager" (cunmin 村民), to describe those living in surrounding villages. What these diverse individuals participating in anti-incineration action share is that they bought apartments outside of the city centre in close proximity to proposed waste infrastructure, some in search of a better environment, to escape the noise and congested air and traffic of city centres, and to take advantage of competitive real estate prices. ${ }^{(15)}$

Zhang Li, in her study of middle class homeowners in Kunming, argues that an important process of class-making in contemporary China occurs through the acquisition of real estate to create spaces of comfort and private retreat. She notes that when developers threaten the process, homeowners typically resort to a form of civic activism. ${ }^{(16)}$ I argue that homeowner anti-incineration protests highlight the fact that attempts by the contemporary Chinese middle class to seek private retreat can never be completely disentangled from certain "publics," in this case, the urban environment. Homeowners inevitably become drawn into the political geographic of urban development and infrastructure as their search for affordable real estate spurs them to participate in debates on waste management.

Two of the most vocal communities making cases against state-sponsored modern waste treatment through WTE incineration in Guangzhou are homeowners from Panyu and Huadu. The southern district of Panyu houses some of the first large real estate developments in Guangzhou. Huadu, an hour's drive north of the city centre, is a more recent development for homeowners who can afford more spacious accommodation for the extended family as a weekend getaway. (17) These large gated communities come with amenities for urban living and in some cases simulate neighbourhoods typical of North American suburbs, with their own grocery stores, restaurants, artificial lakes, elementary schools, and manicured lawns. Private security guards patrol the landscape and residents regularly need to produce identification and proof of residence. Immediately outside the housing complexes lies a collection of villages with segmented fields, ponds for aquaculture, and small to mid-sized factories. Located near both neighbouring factories of the PRD and Guangzhou, these villages do not resemble the empty rural spaces of China's interior provinces. Villagers who leave for work still return home regularly, and migrant workers from outside Guangzhou come in search of housing rentals when they work in nearby factories.

In 2009, news of a proposed incineration facility to be built on top of an existing landfill at Huijiang Village in Panyu quickly spread to residents of several large real estate complexes within $10 \mathrm{~km}$ of the facility. Residents engaged in a series of heated online discussions on housing community message boards. ${ }^{(18)}$ Soon afterward, homeowners drafted a petition against the facility and circulated anti-incineration flyers. Homeowners also began petitioning the government and writing letters to People's Congress delegates. On 23 November 2009, a few hundred people turned up on the public petitioning day for the newly established city management committee (chengguanwei 城管委) to protest the proposed incinerator. The government responded by announcing that it would delay the project and allow for more public consultation. In April 2012, after rounds of reassessment and in order to quell public discontent, the government announced that it would move the project to Dagang, a district about $20 \mathrm{~km}$ from the Panyu city centre. Despite murmurs of disapproval, local villagers at the new site were relocated, and construction began in spring 2013.

Homeowners in Huadu have also been protesting incineration since 2009. A facility initially proposed in 2008 was suspended in 2009 at the same time that the Panyu facility was put on hold. However, in May 2012, residents noticed an announcement of resumption of the project on a government website. Homeowners in several housing complexes began organising monthly visits to the district and municipal governments. In June 2012, homeowners staged a planned protest with several hundred people. Residents continued to attend monthly petitions of the government, and on 12 July 2013, the Huadu district government announced that it would reconsider the original location and proposed another nearby village as their likely first choice for the new project. Residents around the second, newly proposed Huadu site rallied quickly, and two more large demonstrations took place by the end of July 2013. Negotiations between protesters and the government are ongoing.

\section{Framing resistance in China}

I draw primarily on two literatures and debates to frame homeowner protests and resistance in China. First, Kevin O'Brien and Li Lianjiang's concept of rightful resistance offers a valuable model for understanding forms of resistance - especially common in China - that lie somewhere between revolutionary social movements and quiet everyday resistance. ${ }^{(19)}$ Using examples of rural protests, they argue that resisters identify the gap between lower-level government and the types of institutional protection

12. Thomas Johnson, "The Politics of Waste Incineration in Beijing: The Limits of a Top-Down Approach?", Journal of Environmental Policy \& Planning, Vol. 15, No. 1, 2013, pp. 109-128.

13. Since 2009 , Guangzhou's government bureaus have instituted a monthly petitioning day, where residents can meet with officials in person to express their grievances.

14. For example, activists from the Huadu district tend to view Panyu activists as more elite, while residents in Panyu often note the diverse demographic within their own housing development.

15. Some residents are natives of the city of Guangzhou, while others have moved here from different parts of China such as Hunan, Heilongjiang, and Suzhou.

16. Zhang Li, In Search of Paradise: Middle-Class Living in a Chinese Metropolis, Ithaca and London, Cornell University Press, 2010.

17. Homeowners who lived in the community fulltime and those who bought homes primarily for investment participated equally in protests. However, my observations do not account for those homeowners in housing communities affected by incinerators who do not participate in protest or petition events.

18. Online discussion boards are neighbourhood forums for information exchange by residents. Common topics of discussion relate to everyday life, such as information on schools, hospitals, real estate values, and public transportation. Starting in 2009, the topic of WTE incineration and waste treatment became one of the most popular topics on the forum. In one instance, residents posted more than 200 separate discussion threads and comments.

19. Kevin J. O'Brien and Li Lianjiang, Rightful resistance in rural China, Cambridge and New York, Cambridge University Press, 2006. 
granted by higher-level officials to force local compliance. Although O'Brien and Li expand their theoretical model to other countries, their argument derives from rural protests in China and most accurately reflects the conditions of rural protesters who have limited access to information and who tend to emphasise the central government's duty to uphold and protect the rights that citizens have been granted.

Second, Peter Ho and Richard Edmonds' work on "embedded environmentalism" is critical to framing environmental action in China. They argue that contemporary activism - especially environmentalism through non-governmental organisations (NGOs) - is a fragmentary, highly localised, and non-confrontational movement. (20) $\mathrm{Ho}$ and Edmonds characterise this type of activism as "greening without conflict," where the semi-authoritarian limitations on speech and direct confrontation have led to shifts in political strategy that create new opportunities for political organisation and engagement. (21) Their work shows that NGOs often represent a negotiated symbiosis between the Party and state on the one hand and informal social networks on the other. NGOs provide channels of interaction and negotiation with state actors. (22) Purposeful and strategic "depolicitisation" of rhetoric in many environmental movements is therefore not a limiting process but rather an adaptive political strategy that ultimately enables collaboration and resistance within a semi-authoritarian state. Both O'Brien and Ho's theories are especially notable, given that they pay particular attention to both the form and content of citizen contentions within China's political context and highlight modes of resistance of two groups - villagers and environmentalists - especially those working for NGOs or grassroots environmental groups. However, neither O'Brien nor Ho adequately accounts for the method of resistance or the position of new homeowner activists engaged in environmental contentions who are careful to set themselves apart from villagers and yet do not constitute the organised environmentalism of NGOs.

Resistance against facility siting in the West is often framed through the NIMBY literature, and as a result, homeowner activists are often portrayed as localised protesters with narrowly defined interests. The NIMBY literature tries to assess why participants choose to resist local projects, and whether their protests have the potential to transform into larger social movements. The literature has been criticised for a simplistic dualism in its framing of local opposition as driven by limited economic or self-interested concerns, such as real estate value that might or might not lead to larger environmental and social movements. ${ }^{(23)}$ Discussions of NIMBYism in the Western context have recently focused on community opposition to new renewable energy facilities. (24) Other scholars expand the concept to encompass locally unwanted land-use (LULU), or attend to the transition from local opposition to larger environmental movements, or what can be described as the transition from "not-in-my backyard" to "not on my planet" protests. Previous studies of NIMBY movements in Taiwan illustrate that anti-incineration agitation uses local-based oppositional movements to agitate for greater public participation, and that these direct actions coincide with democratic movements. ${ }^{(25)}$ Peng Lin and Wu Fengshi note that while NIMBY mobilisation has grown increasingly violent in China, the Panyu case in Guangzhou represents a departure from NIMBYism because of the transition by activists to policy advocacy. (26)

Generally speaking, the NIMBY literature over-emphasises the distinction between "environmental" claims and localised, "self-interested" contentions and overlooks the range of strategies local actors use to position themselves and their multiple demands within a political context of state repression.
NIMBY framings of environmental politics begin by questioning why activists reject certain projects, paying particular attention to their own logic and reasons (i.e., their concerns about localised pollution), but ultimately relegate individual intentions and meaningful action of actors to a question of whether a particular localised or individualised concern can or cannot scale up into a larger collective social movement. The scope and possibility for this transition from individual to collective resistance is extremely limited in contemporary China. Cai Yongshun has argued that the middle class tends to shy away from activities that threaten the political order because, on the one hand, they benefit relatively more from reform, while on the other, like workers and peasants, they face strong state repression when organising. ${ }^{(27)}$ The arrest of three homeowner activists accused of trying to incite villagers in a protest against an incinerator in Huizhou, Guangdong, on 5 September 2013 illustrates the difficulty of creating collective alliances between villagers and homeowners. ${ }^{(28)}$ One homeowner pointed out that one of the state's greatest fears is increased interaction between homeowners and villagers, and public security was focused on homeowners who approached villagers. ${ }^{(29)}$

Thomas Johnson also highlights the "rationality" that campaigners use to elevate their resistance to incineration siting to a public health issue. ${ }^{(30)}$ Johnson argues that framing the debate in terms of public health allows campaigners to avoid the pejorative NIMBY label and to gain political legitimacy while avoiding forms of politics that overtly challenge the power of the state. As my research shows, the articulation of their demands in terms of "rational resistance" by homeowners is not, however, merely a strategic act to escape the NIMBY label. Rationality also signals the aspiration of homeowners for an alternative form of politics involving new engagement with the process of decision-making around public infrastructure to challenge the legitimacy of state-sponsored science and technology.

The scholarship on the public reception of technology within science studies on how citizens position their own rejection of WTE incineration illuminates the particular logic and effects of citizens' rejection of large infrastructure projects and the ways that citizens draw on claims of science to reject and critique specific state-sponsored technology. ${ }^{(31)} \mathrm{A}$ key contribution of this scholarship is the emphasis on the fact that lay experts and everyday knowledge can often be more effective in providing an assessment

20. Peter Ho and Richard Louis Edmonds (eds), China's Embedded Activism: Opportunities and constraints of a social movement, London and New York, Routledge, 2008.

21. Ibid.

22. Ibid.

23. Kristy Michaud et al., "Nimbyism vs. environmentalism," art. cit., p 1.

24. Patrick Devine-Wright, "Beyond NIMBYism: towards an integrated framework for understanding public perception of wind energy," Wind Energy, Vol. 8, No. 2, 2005, pp. 125-139.

25. Hsu, Shu-Hsiang, "NIMBY Opposition and Solid Waste Incinerator Siting in Democratising Taiwan," The Social Science Journal, Vol. 48, No. 3, 2006, pp. 453-59.

26. Peng Lin and Wu Fengshi, "Beyond NIMBYism, China's Environment Social Mobilisation," China Policy Institute Blog, 8 April 2013, http://blogs.nottingham.ac.uk/chinapolicyinstitute/ 2013/04/08/beyond-nimbyism-chinas-environment-social-mobilisation/ (accessed on 14 March 2014).

27. Cai Yongshun, "China's moderate middle class: The Case of Homeowners' Resistance," Asian Survey, Vol. 6, No. 5, 2005, pp. 777-799.

28. BBC China, "Three people arrested over protesting incineration construction in Guangdong" (in Chinese), 5 September 2013, www.bbc.co.uk/zhongwen/trad/china/2013/09/130905_guangdong_arrests.shtml (accessed on 29 October 2013)

29. Interview, 24 April 2013.

30. Thomas Johnson, "The Health Factor in Anti-Waste Incinerator Campaigns in Beijing and Guangzhou," The China Quarterly, Vol. 214, No. 2, 2013, pp. 356-375.

31. Peter Kirby, Troubled Nature: Waste, environment, Japan, Honolulu, University of Hawai'i Press, 2011. 
of potential risk and pollution. ${ }^{(32)}$ Moreover, environmental controversies have been a powerful force spurring citizen participation in evaluating the legitimacy of scientific claims to support specific technologies, with many citizens using lay science to challenge technologies deemed beacons of modernity and development. ${ }^{(33)}$ In the global north, scholarship on the production of science has challenged the separation of the domains of science and politics and cast it as a fundamental characteristic of modernity. ${ }^{(34)}$ The China case is an interesting example of how citizens in the global south draw on the discourse of rationality to offer a critique of the state's attempt to realise technological modernity in a context where citizens are well aware of the influence of politics over science.

\section{Apart from villagers: Rational resistance as a distinguishing tactic}

\section{"Villagers are full of passion; we [homeowners] are more rational." (35)}

Outside of the municipal city management committee office on petitioning day, individual homeowners, many having taken the morning off from work, arrive one by one to make their case to officials. As villager leaders, having already finished their appeal, emerge from the office, a group of homeowners has started to gather outside. As the villagers leave, they exchange a few words with homeowners. Given the location of incineration facilities on the outskirts of cities, local villagers affected by waste facilities seem to be homeowners' natural allies as they face similar threats of pollution and, rather than a decrease in property value, are often confronted with the more severe threat of relocation. Despite similar protest tactics and interests, however, homeowners strategically emphasise rationality to signal a new distinctive mode of political engagement to set themselves apart from villagers.

"[We rely on] tactics with words rather than with weapons" (wendou bushi wudou 文斗不是武斗). (36) I'm speaking to a homeowner after petitioning day, and the interviewee highlights the importance of rational expression (lixing biaoda 理性表达) in addressing the effectiveness of protest. ${ }^{(37)} \mathrm{A}$ petition letter is presented to me as a sign of their rational appeal. The document contains a lengthy argument drawing on newspaper reports of problems with existing incinerators, NGO cases outlining declining reliance on incinerators in countries such as Japan and Denmark, and scientific reports on environmental standards. An important element of rational expression is the drawing together of facts and sources from recognised domains of knowledge - the media, scientific reports, and policy. Government petitioning days, intended as a space where officials receive grievances from citizens, have become forums of heated exchange between officials and activists armed with prepared speeches and analysis reports. After a successful day of petitioning, homeowners comment, "We left the officials with no words" (tamen dou mei hua shuole 他们都没话说了). ${ }^{(38)}$

In contrast, only a select group of village leaders turns up to represent entire village interests. One homeowner protester, a women in her early thirties employed by a foreign company, tells me that "villagers can only repeat that they are against incinerators, but they never go further to tell you why," implying that villagers are incapable of presenting rational arguments to the state. (39) The comment "we don't know how to speak" (women buhuishuo 我们不会说) is a phrase commonly heard amongst villagers affected by incinerators, especially when talking about difficulties they experience while confronting government officials. As Anna Lora-Wainwright and Bryan Tilt have shown, scholarship linking environmental consciousness to the rising middle class neglects the agency of villagers, who often take action in many ways to assess, mitigate, and resist the impact of local pollution. ${ }^{(40)}$ However, villagers are also sensitive to the structural inequality between themselves and homeowners and their own inability to voice concerns.

Aside from their ability to articulate their arguments and to refer to specific domains of rational discourse and knowledge, homeowners also use the concept of rationality to emphasise their social distinction from villagers by positioning rationality against emotion. By appealing to rationality, housing residents stress their respect for dialogue while explicitly setting themselves apart from the passion (jiqing 激情) of villagers. As another activist, a business owner, tells me: "Us urban residents, we've all been educated and have different ways of handling these protests. We don't want anyone to get hurt. But if we're left with no alternatives, we'll have to think of other options. Take the villagers [for example]; they've been left with no choice. When your life is at stake, no one can be rational." (41) By characterising villagers as more emotional, homeowner activists relegate them to a form of antiquated communist-era politics, as emotion or passion was often emphasised in political campaigns during the Cultural Revolution. ${ }^{(42)}$ What is critical to note in this case is not whether villagers are objectively more emotional in their tactics, but that homeowner activists explicitly emphasise this dual and contradictory framework of emotion and rationality. For homeowners to characterise villagers as emotional and their own form of engagement as rational illustrates a desire for social distinction and a way to set their own political engagement, strategies, and subjectivity apart from that of villagers.

In China, the term baoli (暴力), which denotes extreme or violent tactics, is used to describe any attempt - even a peaceful one - to take to the streets. In the case of anti-incineration organising in Guangzhou, both homeowners and villagers employ similar tactics: typically petitions and street protests. Many homeowners, despite claims to rationality, will often speak about the power of "going on the street" - most often associated with villagers and striking workers - as the most effective mode of protest. Further, during petitions, homeowners will gently but not so subtly "warn" the government that failure to handle the situation "rationally" risks inciting a collective incident (quntishijian 群体事件). In the government petitioning office, seated across from the row of officials, homeowners will whisper to each other, loud enough so that officials have no way of not hearing: "The government better take care when handling the situation, you don't want to end up with another collective incident on your hands." (43) Given previous

32. Brian Wynne, Sheila Jasanoff, Gerald Markel, James Petersen, and Trevor Pinch, "Public Understanding of Science," in Sheila Jasanoff et al. (eds), Handbook of Science and Technology Studies, London, Sage Publications Ltd., 1995, pp. 361-388.

33. Melissa Leach, Ian Scoones, and Brian Wynne (eds), Science and Citizens: Globalisation and the challenge of engagement, London, Zed Books, 2005.

34. Bruno Latour, We Have Never Been Modern, Cambridge, MA, Harvard University Press, 1993.

35. Interview, 2 October 2012.

36. Interview, 12 May 2013.

37. Interview, 12 May 2013.

38. Participant observation, 13 June 2013.

39. Interview, 23 February 2013.

40. Anna Lora-Wainwright, "The Inadequate Life: Rural Industrial Pollution and Lay Epidemiology in China," The China Quarterly, Vol. 214, No. 2, 2013, pp. 302-320; Bryan Tilt, "Industrial Pollution and Environmental Health in Rural China: Risk, Uncertainty and Individualisation," The China Quarterly, Vol. 214, No. 2, 2013, pp. 283-301.

41. Interview, 12 May 2013.

42. Elizabeth J. Perry, "Moving the Masses: Emotion Work in the Chinese Revolution," Mobilisation: An International Journal, Vol. 7, No. 2, 2002, pp. 111-128.

43. Participant observation, 11 May 2013. 
protests in Guangzhou and other protests over large infrastructure projects in cities across China, the warning does not fall on deaf ears. Despite their strategic emphasis on rational dialogue, the threat of more extreme tactics is one way that homeowner activists put political pressure on the government. While they share comparable tactics with villagers, homeowners distinguish themselves through rationality to signal that they are a different social group with a new form of political engagement.

Finally, homeowners view "rationality" as a characteristic of the "politics of individuals" and as separate from the collective social appeals of villagers. Homeowners stress that their status as property owners and their proximity to the facility as residents entitle them to publicly voice their environmental and health concerns. One of the most commonly reiterated claims of homeowners is that each individual has the ability to rationally assess the proposed project and to speak for him or herself. Homeowners often speak of only representing themselves (wo zhi daibiao wo ziji 我只代表我自己) and say that their protests are only for "my own health," and "my own community" (weile wo ziji de jiankang, han wei jiayuan 为了我自己的健康, 捍卫家 园). There is a broad consensus among homeowners that although some are more actively involved in the protest than others, each individual decides the terms of his or her participation, with little need to commit to longterm action. Activists specifically resist being described as part of a particular "organisation" or "movement," and when asked how the group meets, homeowners explicitly emphasise that they "have no organisation" (women meiyou zuzhi 我们没有组织). Their reluctance to be characterised as organised comes first and foremost from an attempt to avoid being perceived as a subversive movement by the state.

The rational individual homeowner protester is set apart from the petitioning village leaders, who are inextricably part of a social collective and dominated by village social hierarchy and politics. When homeowners are asked what sets them apart from the villagers, a common reply is that villagers are more united (tuanjie 团结) or, as one homeowner puts it, they will all listen to their village leaders. This difference can also be seen in the different treatment of these two groups by the state. For example, a homeowner activist recounted that during a petitioning day, a village leader brought a signed petition with more than 500 signatures of villagers, but the government argued that all of these distinct 500 signatures only counted as one single vote against the incinerator. ${ }^{(44)}$

The discourse of "rationality" serves not to identify different protest tactics but rather to establish a social distinction between two groups of political subjects - homeowners and village protesters. The "rational" individualised political figure of the homeowner appears in diametric opposition to his ostensible allies, the villager. Homeowners view villagers as collectives, with some members able to voice political demands while others emote with threats of violence. Homeowners, in contrast, portray themselves as logical individuals capable of articulating their own resistance and engaging in dialogue by drawing on science and knowledge. The discourse of rationality casts villagers as engaged in a politics of force, while positioning homeowners as individuals who are able to engage in a politics of dialogue to challenge the state's modernising technologies.

\section{Against the state: Rational resistance as a social critique of technology}

"Rationality is acting according to the law, but it's obvious that our legal system has many weaknesses; it's even unfair. That's why we have to tell [the government] what people think and they have to listen. I think this is rationality; if the government doesn't listen, then they are being irrational." $(45)$

In her account of the 2009 Panyu protest, Katherine Zhao draws on O'Brien's theory of rightful resistance to examine how "upwardly mobile groups" place political pressure on the Guangzhou government. She highlights homeowners' access to new information technologies and their social capital as unique advantages. ${ }^{(46)}$ The homeowner protester against WTE incineration make arguments that go beyond the types of "rightful resistance" employed by villagers in O'Brien's theory to suggest that rules, policies, and regulations do not fit the specific situation in China and to cast doubt on the ostensible rationality of the government's decisions in the first place. Urban "information-rich" citizens are acutely aware of the discrepancy between centralised policy and local implementation, but in the case of WTE incineration, promotion of the technology is supported by central policy and implemented locally. Citizens appealing to the state must then challenge the logic of state-sponsored technology at every level of government, from the district city management committee to the provincial bureau of environmental protection. While compliance with legal regulations and rules remains an issue, particularly concerning public participation in environmental impact assessments (EIA), what is unique about urban environmental protesters is that their demands extend beyond an appeal that officials follow procedure to challenge the logic of the state's choice of relying on technological solutions.

The strategic deployment of the term "rationality" by homeowners locates their protest within specific modern, logical, and scientific modes of discourse. However, instead of appealing to technological specificities or scientific facts, homeowners rely on a critique of society to express what they deem to be rational or irrational methods of waste treatment. When they petition the government, homeowners point to what is irrational about the government's plans, accusing it of being swayed by business interests, presenting the complicated picture of implementation, and offering their own more scientific solutions to waste. In contrast to the state's vision, for urban homeowners what is rational or scientific requires not only high-tech facilities, but also an overall assessment of the ways that society engages in waste practice.

In order to convince the municipal government to abandon WTE incineration, homeowner activists are faced with the challenge of how to reason and persuasively communicate that the national policy promoting increased use of WTE incineration is an irrational choice. Unlike pollution victims who gather symptoms and catalogue victims in order to highlight the toxicity of their surroundings, new urban environmental controversies increasingly begin at the planning and development stage of the projects prior to facilities being constructed. Activists must make their case based on the amount of assumed "risk" rather than proven damages. First, they must explain why WTE incineration, a technology that is widely used in the West and supported by a government campaign and expert testimony, should be rejected in China. Second, unlike cases in other countries where homeowner activists can rely on science and independent data to make their case and appeal to

\footnotetext{
44. Interview, 15 August 2010.

45. Interview, 5 April 2013

46. Katherine Zhao, "Boundary-Spanning Contention:The Panyu Anti-Pollution Protest in Guangdong, China," Stanford Journal of East Asian Affairs, Vol. 11, No. 1, 2011, pp. 17-25.
} 
third-party sampling and testing, the political context of China makes "science" a difficult ally. Official government rhetoric provides powerful backing to the safety of advanced WTE incinerators. Homeowner activists tell me that in their first attempts to seek help from experts, many question the viability of incinerators off the record, but few are willing to speak publicly. Further, activists lack third-party verification to challenge emissions data. Under (what activists suspect to be) political pressure, testing institutions they contact often back out at the last minute. Finally, lack of access to complete versions of environmental impact assessment reports and emissions data makes it difficult to prove there are irregularities in facilities currently in operation.

The rise of citizen experts is a defining feature of technological controversies, and China is no exception in this respect. ${ }^{(47)}$ Homeowner residents have access to a wide range of resources. They are Internet-savvy and have the skills and knowledge to compare the operation of incinerators in different countries. Homeowners also have the ability to consult professionals with relevant expertise living in the same housing complex. In China, however, where citizens are acutely suspicious of the influence of politics over science, homeowner activists increasingly turn away from arguments based on science and increasingly offer an argument based on the implementation of technology in China. In making a precautionary claim to environmental dangers, citizens seek to present a lay perspective. Michel Callon observed that the goal for the concerned citizens is "not to find one consolidated and replicable proof, but the gradual construction of hypotheses, combining theoretical data with empirical observations, objective and subjective data." (48) Rational resistance hinges on the ability of citizen activists to gradually construct a plausible hypothesis that draws together diverse sources of knowledge, both objective and subjective, in order to make their claim.

The rational case that homeowner activists make for rejecting WTE incineration is less about the "science" of WTE incineration and more about their lack of faith in how projects are implemented on the ground. Activists appeal to a sense of "Chinese exceptionalism" to make a case for why technologies that might be safe in Japan and Europe are unlikely to work in China. Rather than debating the merits of the technology itself, they point to the overall conditions of how incineration works in practice in their own city - a lack of relevant environmental standards, the reality of mixed burning due to the lack of a formalised recycling program, and the weakness of pollution monitoring.

Through online research, citizens draw comparisons between China and other developed countries, especially those with similar urban forms and cultural traditions such as Japan and Taiwan. Homeowners first question the overall conditions for safe burning given the cost-cutting practices of most industries in China. As one homeowner tells me, these companies meet standards during the day (when monitors are working) and emit at night (when no one is around to catch them). ${ }^{(49)}$ Activists point to existing complaints over the only WTE incinerator in the city - held up by municipal officials as a model project - especially the accusation by local villagers of the incinerator burning below what is commonly considered to be a safe temperature. ${ }^{(50)}$ While both homeowners and villagers questioned the efficacy of technology, homeowners explicitly frame the problem of implementation as an irrational waste management policy, arguing that if the city's model project is so rife with problems, incineration in China cannot be reasonably trusted as safe.

A second point of contention is that the lack of recycling programs in China often leads to mixed burning. Activists point to countries in Europe to argue for the importance of recycling in order to prevent toxins generated by incinerators. As residents argue, "They tell us that they are bringing in the latest technology from Denmark, but why can [incinerators] work so well in Denmark? Because they've been recycling for over 30 years." (51) Huadu activists claim that the proximity of industrial facilities, such as a local leather factory, will mean the burning of not only household waste but also leather straps and other industrial waste. The case against mixed burning illustrates a deeper critique of overall mismanagement of material flows leading to toxic results. The critique of the failure of waste sorting links the question of the safety of WTE incineration technology to the larger problem of implementing municipal-run recycling programs in China. As a consequence, the issue becomes much broader than questions of advanced technology and instead touches on crucial concerns about the cooperation and commitment of governments and citizens to environmental programs. Finally, citizen activists highlight the lack of public, transparent systems for environmental monitoring and assessment. They also draw advice from a network of their neighbours who are environmental engineers and professionals to make a case for the inexperience of the operators selected by the state. They argue that these inadequate standards increase the risk and uncertainty associated with operating incinerators in China. One resident points out that up to 20 different contaminants from incinerators are monitored in Japan, while even a request to the environmental bureau to release the data for ten pollutants from the local incinerator in Guangzhou came back incomplete. ${ }^{\left({ }^{2} 2\right)}$ Another homeowner sums it up: "[The government] tells us that our technology is cutting edge, but our management structure is perhaps only third-tier." (53)

\section{Conclusion: Urban environmental contentions, new pressures and divisions}

With Chinese cities expanding more rapidly and further outwards, the planning, development, and operation of urban infrastructure will face more scrutiny from urban citizens. Homeowner resistance to WTE incineration in Guangzhou represents a prominent example of China's rising urban environmental contention. I argue that "rational resistance" is an important way for housing residents to frame their own logic, to depoliticise their actions, and to appeal to institutionalised channels. More importantly, I suggest that the appeal to rationality and knowledge functions as a way for homeowner activists to set themselves apart from villagers and the state. The explicit attempt by homeowners to distinguish themselves from villagers illustrates the different and uneven ways that urbanites and villagers on the outskirts of cities confront science and technology. Homeowners' tendency to draw a division between their own claims and those of villagers using the concepts of rationality speaks to the formation of a new political subject and method of resistance through anti-incineration protests. Whereas urban homeowners are engaged in new "rational" critiques, villagers are equated

47. Thomas Johnson, "Environmentalism and NIMBYism in China: Promoting a rules-based approach to public participation," Environmental Politics, Vol. 19, No. 3, 2010, pp. 430-448.

48. Michel Callon, Pierre Lascoumes, and Yannick Barthe, trans. Graham Burchell, Acting in an Uncertain World: An Essay on Technical Democracy, Cambridge, MA, MIT Press, 2011 p. 215.

49. Interview, 7 February 2013.

50. Li Jiawen, "Incineration at $850 \mathrm{C}$ at Likeng won't dissolve plastic bags?" (in Chinese), Xinkuai News, 24 August 2012.

51. Interview, 5 April 2013.

52. Interview, 29 June 2013.

53. Interview, 5 April 2013. 
with an antiquated form of political engagement. These distinctions raise questions about what forms of cooperation, exclusion, and othering are developing between urbanites and villagers against the backdrop of urban environmental protest and resistance. Rather than just another form of NIMBYism, rational resistance also represents a broader critique of statesponsored technology and a desire to draw social distinctions between two groups of urban political subjects.

The emphasis on the "rationality" of technological choice by homeowners also challenges the modernising visions of the state. Homeowners highlight the concrete reasons that WTE incineration is not suitable for China by relying on a deeper social critique of the material flows of society and expose the distance between China's struggle to introduce modern infrastructure and its promise of building world-class cities. Pointing to the gap between Chinese incinerators and incinerators in the West, urban activists engage in a political critique of society, specifically the lack of environmental management and social regulation around urban infrastructure and technology. More importantly, they point to the inability of the government to convince the public to trust the safety of its pollution monitoring structure. The problem of waste management, in the eyes of homeowners, is not a technological problem but a social one.

The emphasis on rationality has implications for the scholarship on science and technology studies outside of the Western context. Rather than seeing citizen contentions as a case of NIMBY politics, I stress the importance of attending to the specific claims that homeowners offer to illustrate the irrationality of the state in relying on technological fixes to social problems. I argue that this represents a broader social critique of the politics of urban infrastructure rather than an attempt to defend local interests. Scholars in science and technology studies point out that the separation of science and society is false and a byproduct of modernity. ${ }^{(54)}$ In China, this fact is painfully evident to citizen activists. ${ }^{(55)}$ Public resistance to state-led technologies draws on new forms of knowledge and offers a broad political critique of the reality of incineration implementation in China. In doing so, the China case offers an interesting contrast to science and technology studies literature in the West that engages with technological controversies and the public reception of technology. The attitude of homeowner activists reveals deep ambivalence towards Chinese modernity, and towards science and technology: on the one hand, they embrace the discourse of rationality to represent the logic and reason of their tactics and also as a distinguishing practice from other participants in the urban resistance, namely villagers. On the other hand, citizens are deeply critical of the state's claims to and use of rationality to inform the construction of modern cities.

Rational resistance is best understood as both a protest strategy and as a set of new demands by urban protesters. This framing is especially important at a time when citizen-government dialogue on environmental issues is becoming more commonplace and is taking place in diverse forums. Public discussions on waste and gestures of openness by the state have created new avenues and opportunities for citizen participation. Ongoing media coverage and discussion forums on weibo ${ }^{(56)}$ have made waste a focus for public engagement. Most notably, the Southern Media Group, one of the most liberal papers in China, played an active role in the 2009 Panyu protests, making it one of the best publicised anti-incineration protests in China. A local NGO focused on recycling grew out of the Panyu movement, and it hosted a number of public lectures in 2012. These dialogues echo what science and technology studies scholars have identified as the development of "hybrid forums," where scientists, experts, activists, and concerned citizens are brought together to form a collective. ${ }^{(57)}$

The nature and effect of urban environmental contention in China is still emerging, and homeowner protesters might open different channels of debate and potentially reinforce current divisions in new forums and modes of engagement. Within these emerging "hybrid forums," who can speak and represent their interests to the state? The urban incineration debate in Guangzhou illustrates that through the discourse of "rationality," homeowners and villagers are representing themselves as separate categories of environmental protesters. These categories highlight and expand the ruralurban divide in China against the backdrop of new engagements with science, technology, and the state and raise important questions about what forms of exclusion and collaboration might emerge in China's developing urban environmental politics.

\section{Amy Zhang is a PhD candidate in the Joint Program in Anthropology and Forestry and Environmental Studies at Yale University. Department of Anthropology, 10 Sachem St., New Haven, Connecticut, 06511, USA (amy.zhang@yale.edu).}

54. Bruno Latour, We Have Never Been Modern, op. cit., p. 11.

55. Susan Greenhalgh, Just one child: Science and policy in Deng's China, Berkeley, University of California Press, 2008. See also, Xin Liu, The mirage of China: Anti-humanism, narcissism, and corporeality of the contemporary world, New York, Berghahn Books, 2009.

56. Weibo is an online social networking tool similar to Twitter.

57. Michel Callon, Pierre Lascoumes, and Yannick Barthe, trans. Graham Burchell, Acting in an Uncertain World, op. cit., p.17. 